\title{
40. SEISMIC STRATIGRAPHY OF THE CONTINENTAL SHELF OFFSHORE GUATEMALA: IMPLICATIONS FOR VERTICAL TECTONICS RELATED TO SUBDUCTION ${ }^{1}$
}

\author{
John W. Ladd, Lamont-Doherty Geological Observatory of Columbia University \\ and \\ Sigrid Schroder, 1005 Preston Tower, Dallas, Texas ${ }^{2}$
}

\begin{abstract}
Seismic reflection data on the shelf offshore Guatemala reveal the stratigraphy of the forearc basin that has developed as the result of Tertiary subduction on the site of a Cretaceous passive margin. Abyssal Cretaceous and Paleocene sequences that presently dip landward to the northeast probably originally downlapped across a seaward-dipping continental rise surface. The termination of the thick Paleocene sequence at the shelf edge is probably a postdepositional tectonic truncation. A bathyal Eocene-Oligocene sequence deposited in the forearc subsequent to the initiation of subduction is truncated by a sharp angular unconformity, which indicates severe tilting and erosion of the forearc basin prior to subsidence and the deposition of the seaward-thickening early Miocene sequence. A late Miocene and Pliocene unit thins seaward, indicating renewed uplift of the shelf edge. A Quaternary sequence progrades across the gently tilted upper Miocene-Pliocene sequence toward San José Canyon.

Major unconformities of the forearc basin were coeval with major plate reorganizations. A major reorganization of the Pacific-Farallon spreading center, which occurred in the late Paleocene, may have coincided with or preceded the uplift of the Guatemala shelf edge and the inception of subduction in this region. A late Oligocene disruption of the Farallon Plate forming the Nazca and Cocos plates coincided with renewed subsidence of the shelf edge associated with the seaward-thickening early Miocene sequence. In the middle Miocene another plate reorganization, which led to a much shortened Pacific-Cocos plate boundary, may have coincided with renewed uplift of the shelf edge. The regional Pliocene-Pleistocene unconformity may be associated with an eastward jump in the Pacific-Cocos spreading center from the Mathematician spreading center to the present East Pacific Rise.

The causal mechanism relating plate reorganizations to ocean margin crustal dynamics may involve the changing pattern of forces driving an oceanic plate as the size and shape of the plate change.
\end{abstract}

\section{INTRODUCTION}

The Middle America Trench, which runs from the Rivera Fracture Zone off the Pacific coast of Mexico to the Cocos Ridge off Costa Rica, is the seawardmost element of a broad zone of convergence that is the boundary between the Cocos Plate and the North America Plate north of the Motagua-Polochic fault zones of Guatemala and the boundary between the Cocos Plate and the Caribbean Plate south of the Guatemala fault zones.

Landward of the Middle America Trench the convergence zone generally includes a landward slope between the Trench and the continental shelf and a volcanic chain eastward of the continental shelf. The nature of the shelf differs dramatically along strike: off Mexico the shelf is narrow and apparently underlain by a granitic extension of continental rocks (Shipley et al., 1982), whereas farther south off Guatemala the shelf is underlain by a thick sediment forearc basin of Cretaceous and Tertiary sedimentary rocks probably lying on a piece of oceanic crust (Seely et al., 1974; Seely, 1979; Ladd et al., 1982). A structural high onlapped by Tertiary sediments is generally found at the seaward edge of the forearc basin offshore Guatemala. The landward slope is also quite varied-off Mexico many landward-dipping reflections

${ }^{1}$ von Huene, R., Aubouin, J., et al., Init. Repts. DSDP, 84: Washington (U.S. Govt. Printing Office).

2 Addresses: (Ladd) Lamont-Doherty Geological Observatory of Columbia University, Palisades, NY 10964; (Schroder) 1005 Preston Tower, Dallas, TX 75225. seen on seismic data apparently correlate with sand beds that had been accreted to the margin in the late Tertiary (Moore, Watkins, et al., 1979). Off Guatemala, on the other hand, few landward-dipping reflections are seen on seismic records, and they may correlate with landward-dipping slabs of oceanic crust that may have been emplaced in the early Tertiary (Ladd et al., 1982). Drilling on the landward slope (von Huene, Aubouin et al., 1980; Aubouin, von Huene et al., 1982a, 1982b, and this volume) suggests that there has been little or no sediment accretion since the emplacement of Cretaceous rock at the foot of the slope. This evidence for episodic accretion is in contrast to the steady-state model suggested by Seely et al. (1974).

Various authors have suggested that basement flooring the forearc basin may be a sliver of oceanic crust isolated from oceanic crust to the west of the Trench by an initial rupture of the lithosphere that led to the Middle America Trench subduction zone. Subsequent to this rupture the structural high at the shelf edge developed as a result of progressive underthrusting of sediment and lithosphere beneath the isolated slice of lithosphere, which led to progressive uplift and tilting of this residual forearc basin (Seely, 1979; Ladd et al., 1978, 1982; Couch and Woodcock, 1981). Magnetic and gravity data indicate that a basement high follows discontinuously the continental shelf edge from the Gulf of Tehuantepec off Mexico southward to the Nicoya Peninsula off Costa Rica where an Early Cretaceous ophiolite complex crops out (Dengo, 1962; Couch and Woodcock, 1981; Lund- 
berg, 1982). Seismic refraction studies off Guatemala indicate two landward-dipping units with velocities and thicknesses appropriate for oceanic crust (Ibrahim et al., 1979). Sediments drilled on the shelf edge by Exxon almost immediately above acoustic basement were deposited at abyssal depths, indicating that thin, probably oceanic crust forms basement (Seely, 1979).

Accretion and understuffing of successive sediment packets along a convergent margin have been thought to form such highs and associated basins with concomitant deformation and imbrication of trench inner slope sediments as subduction proceeds (Seely et al., 1974; Dickinson and Seely, 1979). Seismic profiling and DSDP (Deep Sea Drilling Project) drilling off Guatemala have revealed that the Trench floor sequences and forearc basin sequences are not compressionally deformed, whereas the inner slope sediment sequences show evidence of overconsolidation, perhaps related to tectonism, and inner slope ultrabasic rock sequences are highly fractured. On the inner slope, however, drilled sequences are not repeated by imbrication, but are offset only by normal faults (von Huene et al., this volume). At DSDP Site 494 on the lower slope, drilling yielded an apparently normal Cretaceous through Paleogene section (von Huene, Aubouin et al., 1980; Aubouin, von Huene, et al., 1982a). Drilling and seismic surveys at the shelf edge offshore Guatemala suggest that there was rapid uplift from abyssal to middle bathyal depths with only minor tilting of the shelf in the late Paleocene to early Eocene (Seely et al., 1974; Seely, 1979). A prominent angular unconformity at the base of early Miocene sediments on the shelf suggests Oligocene tilting of the forearc basin, yet the fauna from the well at shelf edge indicate approximately constant water depth for this period. Apparently once the shelf-edge structural high was uplifted in the late $\mathrm{Pa}$ leocene it often acted as a hinge for Tertiary subsidence of the forearc basin.

In this chapter we wish to show the stratigraphy of the forearc basin on the shelf offshore Guatemala and relate this stratigraphy to changing patterns of seafloor spreading to the west. A grid of seismic data was collected on the shelf off Guatemala by the University of Texas Marine Science Institute in 1977 and 1978. This data set (Fig. 1) was part of a site survey in preparation for the series of DSDP holes on the landward slope of the Middle America Trench offshore Guatemala.

In the vicinity of the well described by Seely (1979) we tie University of Texas seismic lines to the seismic line published by Seely. We carry the sequence boundaries defined by Seely around the seismic grid to show the threedimensional form of the seismic units. The resulting pattern shows a Cretaceous unit that thins seaward as it downlaps across an originally seaward-dipping surface. Above the Cretaceous sequence is a Paleocene sequence of uniform thickness overlain in turn by an Eocene-Oligocene sequence that thins seaward. To the northwest the seaward thinning is caused by an overlying angular unconformity, whereas to the southeast the base of the sequence progrades or downlaps across the Paleocene with little apparent truncation of the top. A lower Miocene sequence thickens seaward, and an upper MiocenePliocene section has either a constant thickness or thins seaward beneath a Quaternary sequence. There is great variability along the margin in the cross-sectional shape and internal reflection configuration of the upper sequences. On some sections the Quaternary sequence is

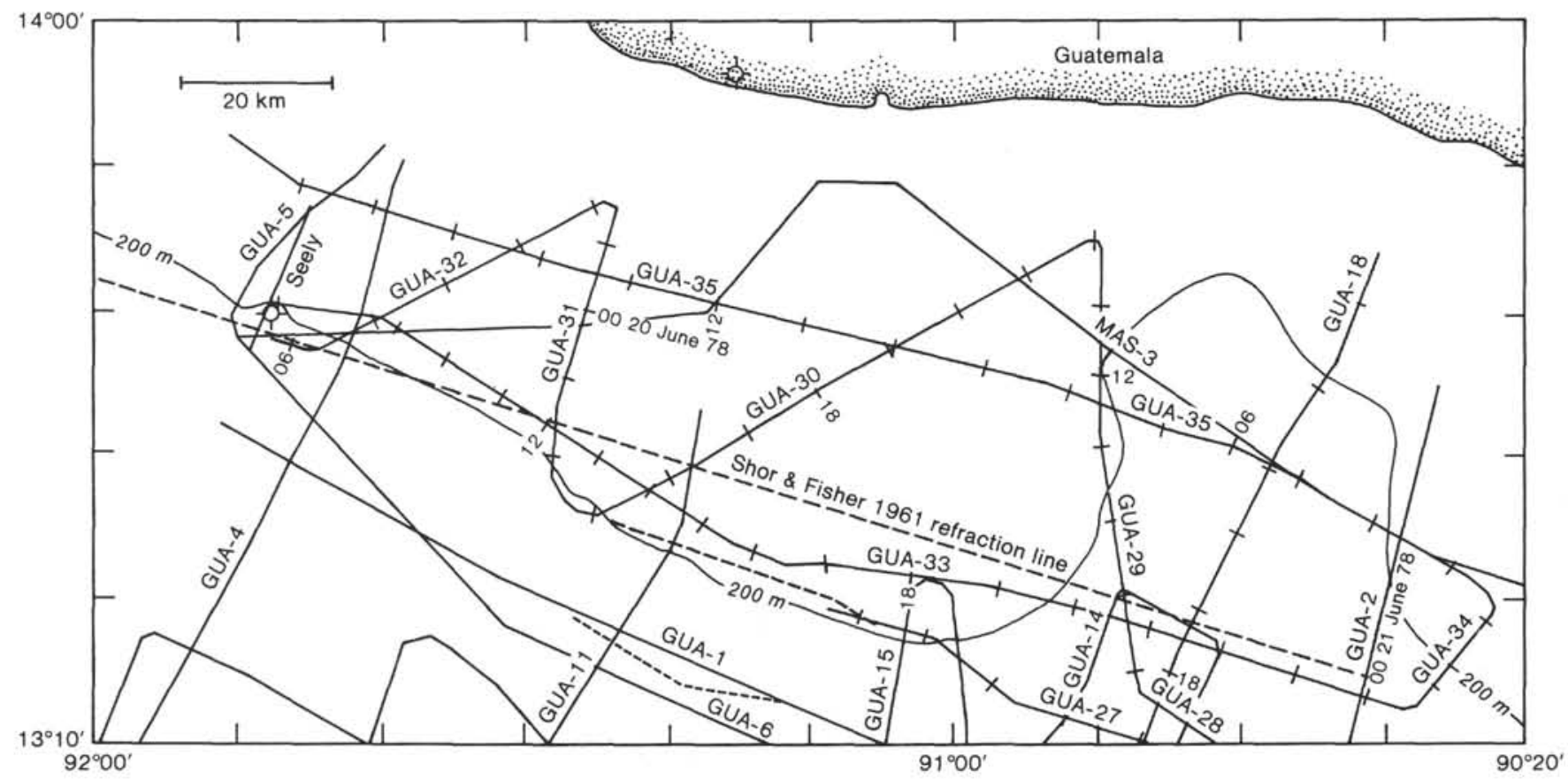

Figure 1. Track chart showing the locations of seismic lines discussed in the text. Tick marks indicate the even hour during ship navigation. Every six hours the time is annotated along the track. The well discussed by Seely (1979) is indicated at the shelf edge near line GUA-5. Another proprietary well is located just onshore in Guatemala. 
of uniform thickness over a broad stretch of shelf, but in other sections it thins by onlap across the sequence below it. In some areas the Miocene-Pliocene unit has apparently constant thickness across the outer shelf; on other parts of the shelf it thins by erosional truncation at its upper surface.

A major feature on the shelf and slope is San José Canyon (Fig. 2). As much as 20 to $30 \mathrm{~km}$ wide, the Canyon has a V-shaped cross section modified by slumping and infilling. The Canyon now funnels fine sediment down the slope into the Trench (K. J. McMillen, personal communication, 1979). Both constructional and erosional episodes are recorded in the canyon walls. As was first noted by Whitcroft (1944), the canyon trend coincides with an offset of the volcanic chain on land and bathymetric contours offshore. Figure 3 shows that offset of the magnetic anomalies occurs slightly to the west of the Canyon axis (Ladd et al., 1978). San José Canyon also follows the general trend of the Guatemala City graben located north of the volcanic chain. Though perhaps coincidental, these alignments may indicate development of the features along a single tectonic trend. Carr and Stoiber have suggested that as portions of the underthrusting Cocos Plate descend beneath Central America with differing dips and strikes, the Plate tears along faults that trend perpendicular to the continental margin (Carr et al., 1974; Carr and Stoiber, 1977). Perhaps this segmentation of the margin is related to alongstrike changes in sediment patterns seen in our seismic lines from the forearc basin.

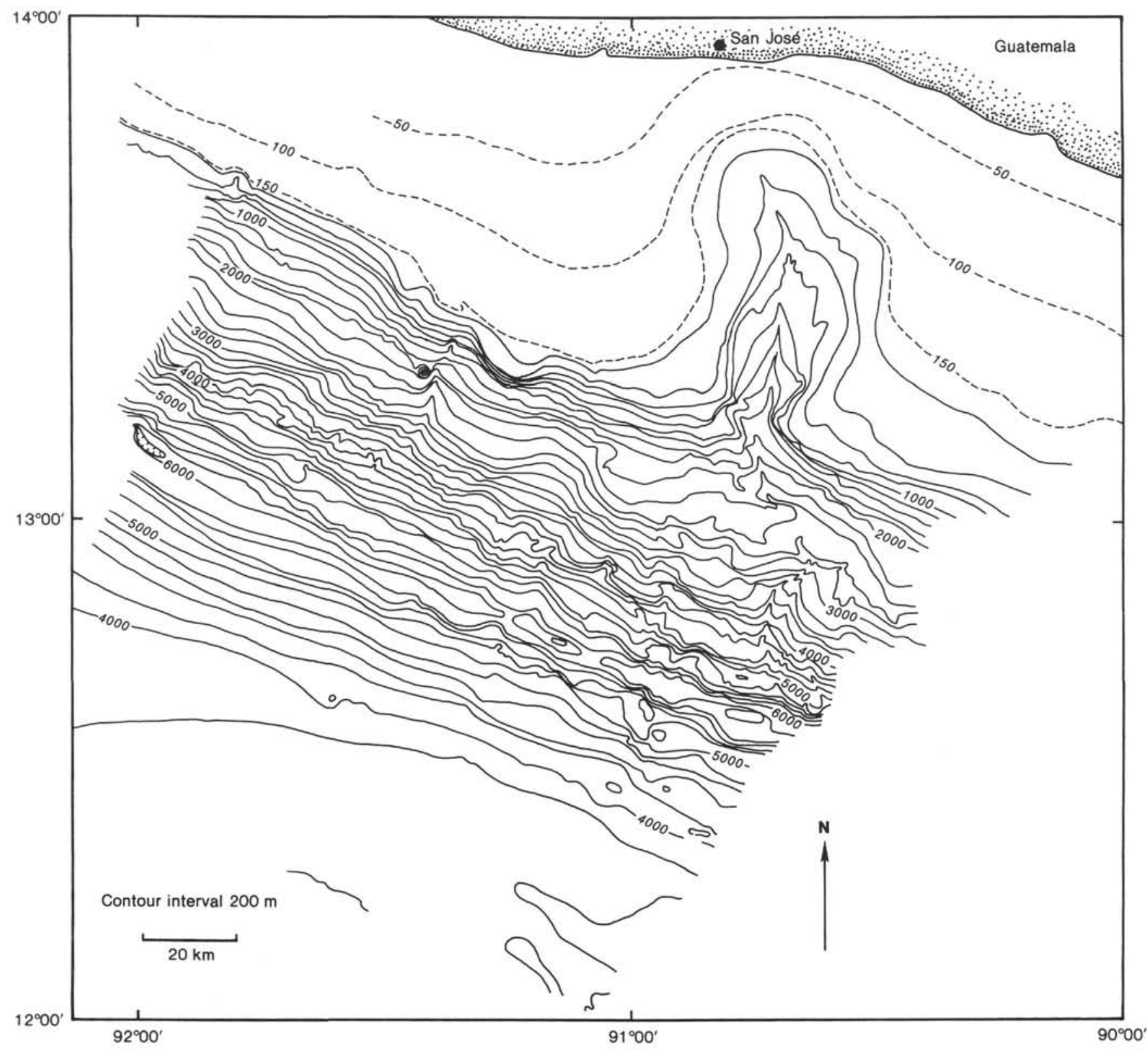

Figure 2. Bathymetry offshore Guatemala (from Ladd et al., 1982). 


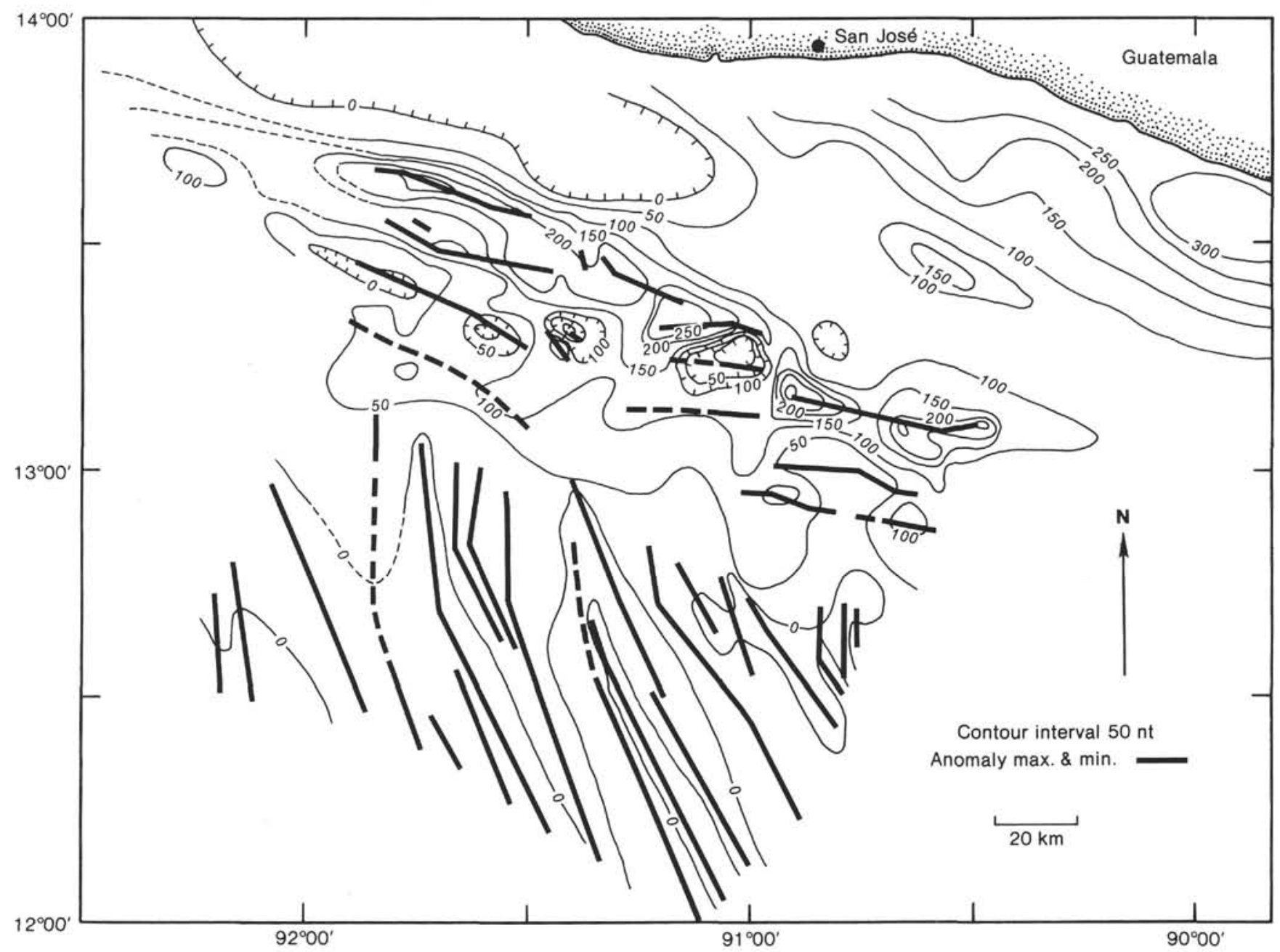

Figure 3. Magnetic anomaly contour map with black bars indicating major lineations. Most striking is the contrast between the ocean crust grain in the southern portion of the map and the shelf-edge grain to the north (from Ladd et al., 1982).

\section{DATA ACQUISITION AND PROCESSING}

Twenty-four-fold multichannel seismic reflection data were collected by the University of Texas Marine Science Institute's Ida Green in 1977 and 1978. Three 1500 -in. ${ }^{3}$ Bolt air guns fired at 300 psi constituted the seismic source. The data were recorded digitally on a Texas Instruments DFS 10,000 in 1977 and a DFS 3 in 1978. Processing was done at the Institute, using a Petty-Ray TEMPUS computer system. Stacked data were filtered with a band-pass filter of 5 to $50 \mathrm{~Hz}$ and scaled with an AGC window of $500 \mathrm{~ms}$.

\section{THE SEISMIC STRATIGRAPHY OF THE FOREARC BASIN}

Stratigraphically the forearc region is complex, with vertical tectonic movements superimposed on changing sedimentary regimes and eustatic sea-level changes. Primary reflections are from sedimentary horizons, and reflection discontinuities result from changes in facies and in horizon dips and from faulting on various scales. Though cycle terminations are used to identify seismic sequence boundaries (Vail et al., 1977), they also may indicate faulting. Data tend to deteriorate along and below faults, and the correlation of reflections across faults is complicated by lateral and vertical changes in strike, dip, and throw of faults.
We use Seely (1979) as a starting reference for our seismic stratigraphy. Seely used the results from an Exxon well to date a series of seismic sequences he identified on an Exxon seismic line that parallels our lines GUA-5 and GUA-4 and lies between these two lines. We can see the same unconformities on our lines that Seely saw on his, so we start our stratigraphy by jump correlating our unconformities to Seely's (Fig. 4). We label the unconformities $\mathrm{C}$ through $\mathrm{F}$. We also identify an unconformity B in the region of Exxon Well, and an unconformity that we call A can be seen to the southeast on our data. These unconformities bound seismic sequences that form the basic framework of the forearc stratigraphy. For ease of reference we have numbered the seismic sequences as indicated in Figure 4. The age assignments indicated on Figure 4 are from Seely (1979). Because they were obtained from a well drilled at the thinnest edge of the sediment basin, these ages should be considered only approximate. For instance, no Oligocene was found in the Exxon Well, but Oligocene may indeed be found farther landward in the basin.

The shelf-edge structural high and the seaward portion of the forearc basin are well illustrated by seismic 


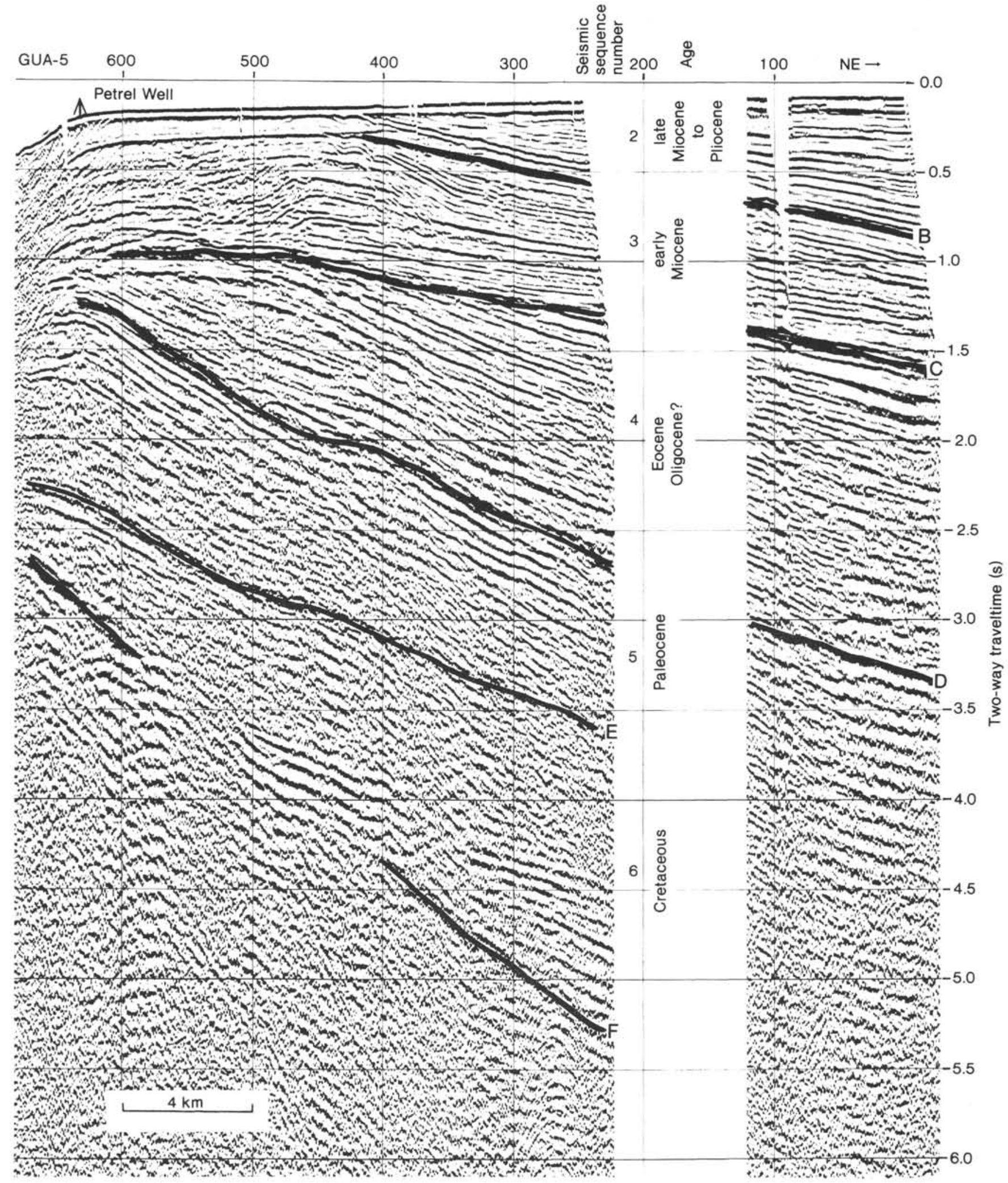

Figure 4. Seismic line GUA-5, which runs near the Petrel Well described by Seely (1979). The sequence boundaries and ages indicated are determined by jump correlating from Seely's published section. Seismic sequences are given numbers 1 to 6 . Sequence boundaries are given letter designations. Note how Sequences 5 and 3 thicken seaward and are then laterally truncated beneath the shelf edge. Sequence 5 suddenly loses reflector continuity beneath the shelf edge. Sequence 3 loses reflector continuity in its lower part and is truncated by erosion in its upper part. Shot point numbers are annotated along the top of the section. 
lines GUA-5 and GUA-4B (Figs. 4 and 5). Here a thick sedimentary section dips landward from the shelf-edge high, the interior of which essentially lacks coherent reflections. The thick Upper Cretaceous and lower Tertiary package is truncated by a prominent angular unconformity suggested by Seely (1979) to represent subaerial erosion during the mid-Oligocene and subsequent subsidence of the basin and of the high. An age-equivalent hiatus was found on the lower slope at DSDP Site 494. A fairly thick upper Tertiary sequence above this major unconformity shows a progradation across the shelf edge. This sequence has been tilted gently landward with subsidence and filling of the basin.

\section{Upper Cretaceous and Lower Tertiary}

The Upper Cretaceous and lower Tertiary seismic sequences are best defined on three dip sections, GUA-4B, -5 , and $-2 \mathrm{~A}$, (Figs. 5, 4, and 11). A thick sequence of Upper Cretaceous sediments onlaps possible basement between shot points (SP) 2350 and 2650 on GUA-4B and between 250 and 600 on GUA-5. On line GUA- 5 the Cretaceous section appears continuous across $\mathrm{F}$ between

GUA-4B

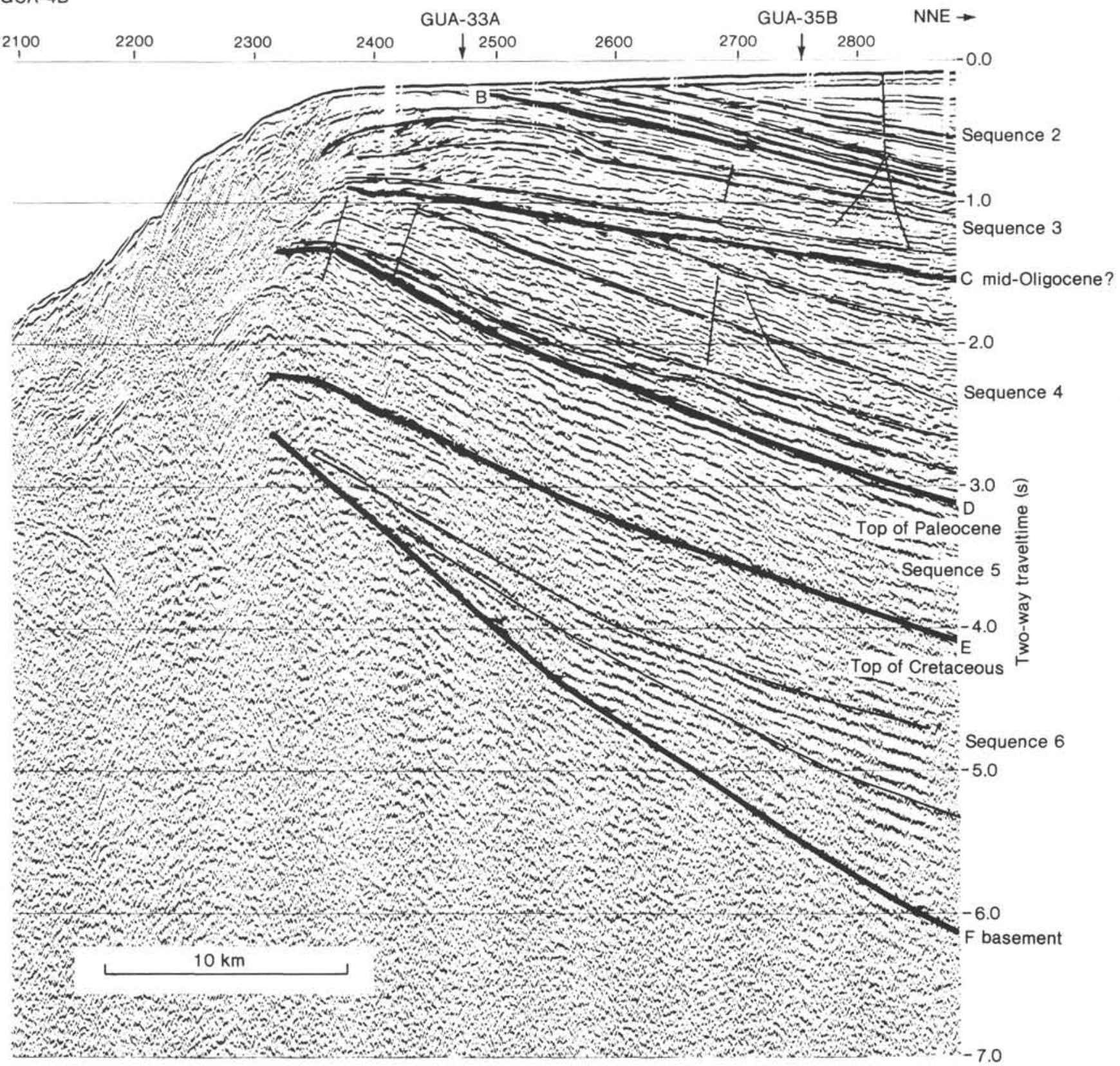

Figure 5. Seismic line GUA-4B, similar in configuration to GUA-5. Seismic Sequences 5 and 6 (see Fig. 4 for Sequence identification) below horizon D were probably deposited on seaward-dipping surfaces of an ancient passive margin in abyssal water depths. Horizon D marks the inception of the convergent margin and uplift and formation of the shelf edge. Further uplift, tilting, and erosion formed horizon $\mathrm{C}$ in the midOligocene before subsidence permitted the accumulation of Sequence 3. 
shot points 400 and 600 , which raises a serious question as to whether $\mathrm{F}$ is really a primary reflection or a multiple of some shallower horizon. On the other hand, the apparently thick Cretaceous section may appear thicker than it really is because of ringing caused by the very narrow band width of signal returning from that depth. The crosscutting relationship is not seen on Seely's figure 9 (1979) or on other lines discussed here. According to Seely (1979), these sediments are predominantly montmorillonitic shales deposited at abyssal depths. Restored to a position before uplift of the structural high, the sequence would downlap onto reflector $\mathrm{F}$.

Above the Upper Cretaceous sequence is a thick $\mathrm{Pa}$ leocene sequence itself onlapped by basin-filling Eocene sediment as is seen on GUA-4B (SP 2350-2500) and on GUA-5 (SP 400-600) and GUA-2A. At the Exxon Well the Paleocene sediments accumulated at abyssal depths followed by middle and late Eocene sediments deposited at middle or upper bathyal depths. From this Seely has inferred absolute vertical movement upward of the shelfedge high and seaward edges of the deep sequences at the end of the Paleocene or in the early Eocene. The Paleocene sequence had a fairly uniform thickness across the outer shelf or thickens slightly seaward. Horizon E where it can be seen mildly truncates the Cretaceous and is in turn onlapped gently landward by the Paleocene (see Figs. 4 and 11). Horizon D that separates the Paleocene from the Eocene is conformable to the Paleocene and is onlapped by the Eocene in a seaward direction (see Figs. 4, 5, and 11).

\section{Upper Tertiary}

The pronounced major sequence boundary $\mathrm{C}$ truncates the lower Tertiary sequence, and it is prominent throughout the grid. Above this boundary the sequences are far more distinct than those below. $\mathrm{C}$ is typically a strong, highly continuous reflection that truncates the lower Tertiary sequence on GUA-4B between shot points 2450 and 2750 (Fig. 5). C bevels the shelf-edge high and continues landward as an angular unconformity, as dip lines GUA-4B and GUA-5 and strike lines GUA-33 and GUA-35 (Figs. 6-9) illustrate.

Seely (1979) assigns C to the post-Eocene to early Miocene; however, this is a maximum range for the age of $\mathrm{C}$ because the Exxon Well was not located in the center of the forearc basin where it could have sampled younger section beneath the unconformity. This age coincides generally with the mid-Oligocene hiatus in Central American volcanic activity discussed by Malfait and Dinkelman (1972) and with a large global Oligocene marine regression (Vail et al., 1977). C is the age equivalent of an unconformity on the lower slope interpreted to represent a hiatus from the upper Eocene through the midOligocene (von Huene et al., 1980).

Though boundary D between the Paleocene and Eocene sediments at the shelf edge is interpreted by Seely

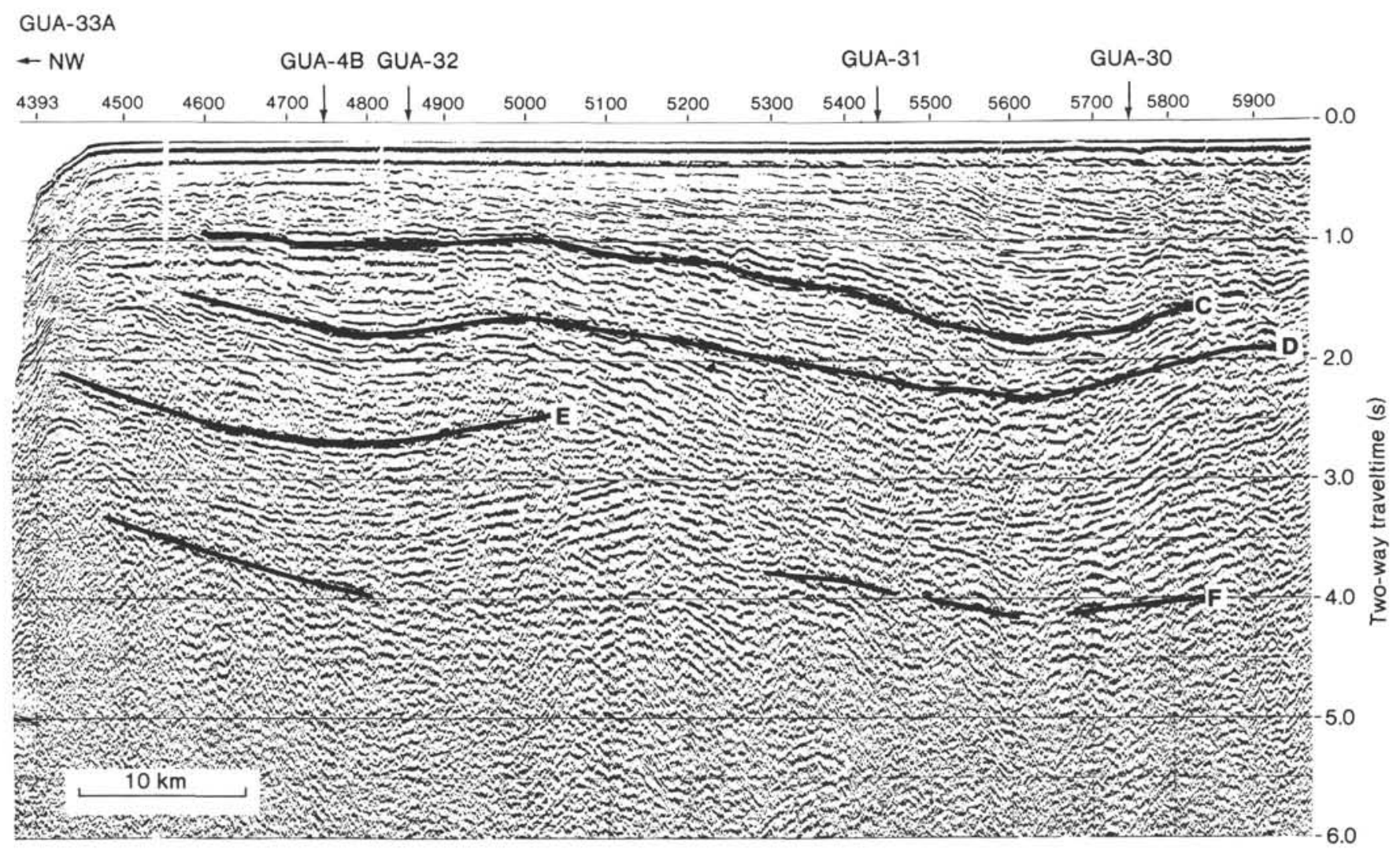

Figure 6. Seismic line GUA-33A along the shelf edge. Shot points are annotated along the top along with the location of crossing points with other seismic lines. 


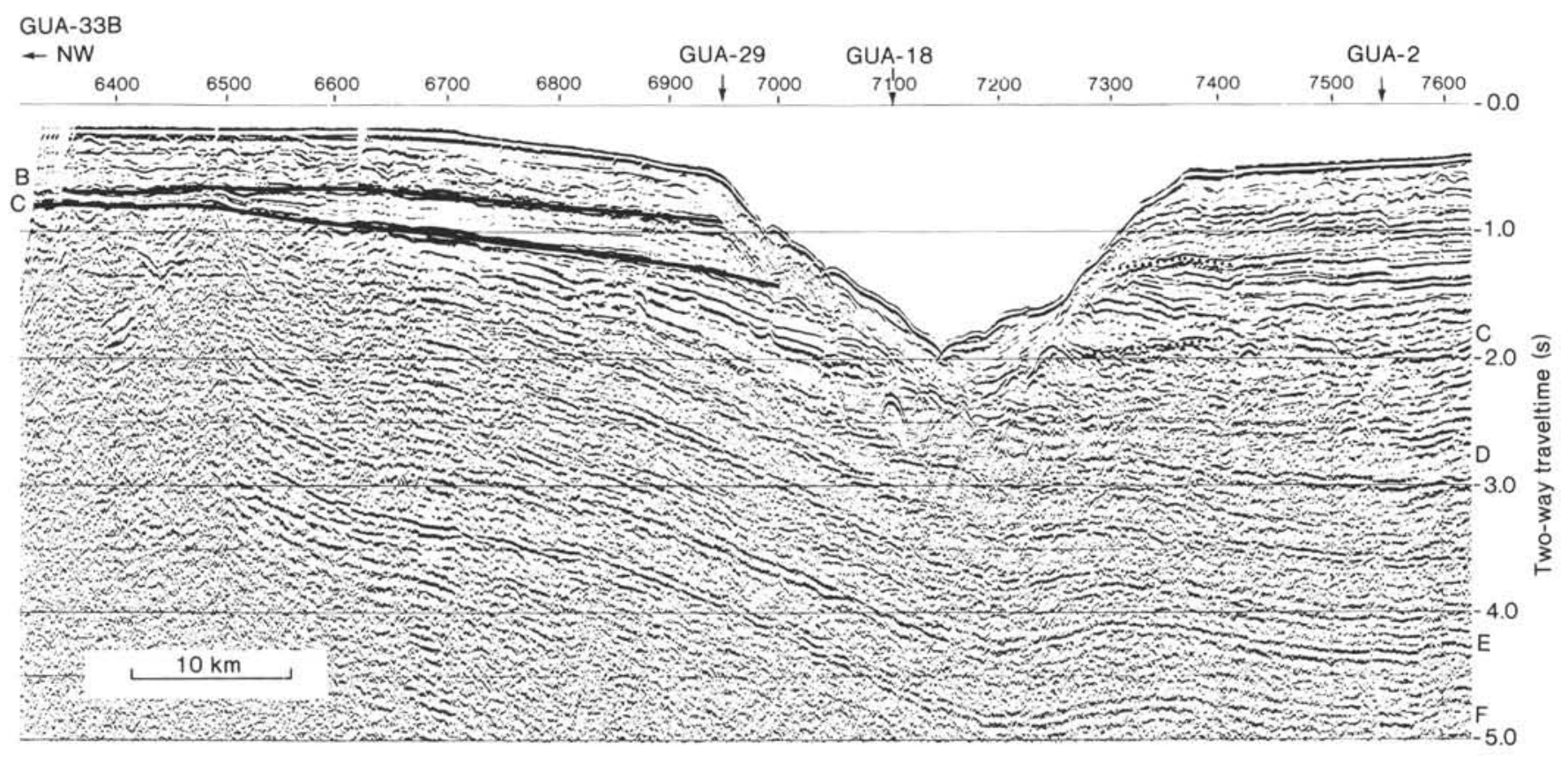

Figure 7. Seismic line GUA-33B across San José Canyon. The apparent flexure of the deeper layers beneath the Canyon is probably because of a course change of the seismic boat so that the line is more nearly parallel to the shelf-edge high east of the Canyon.

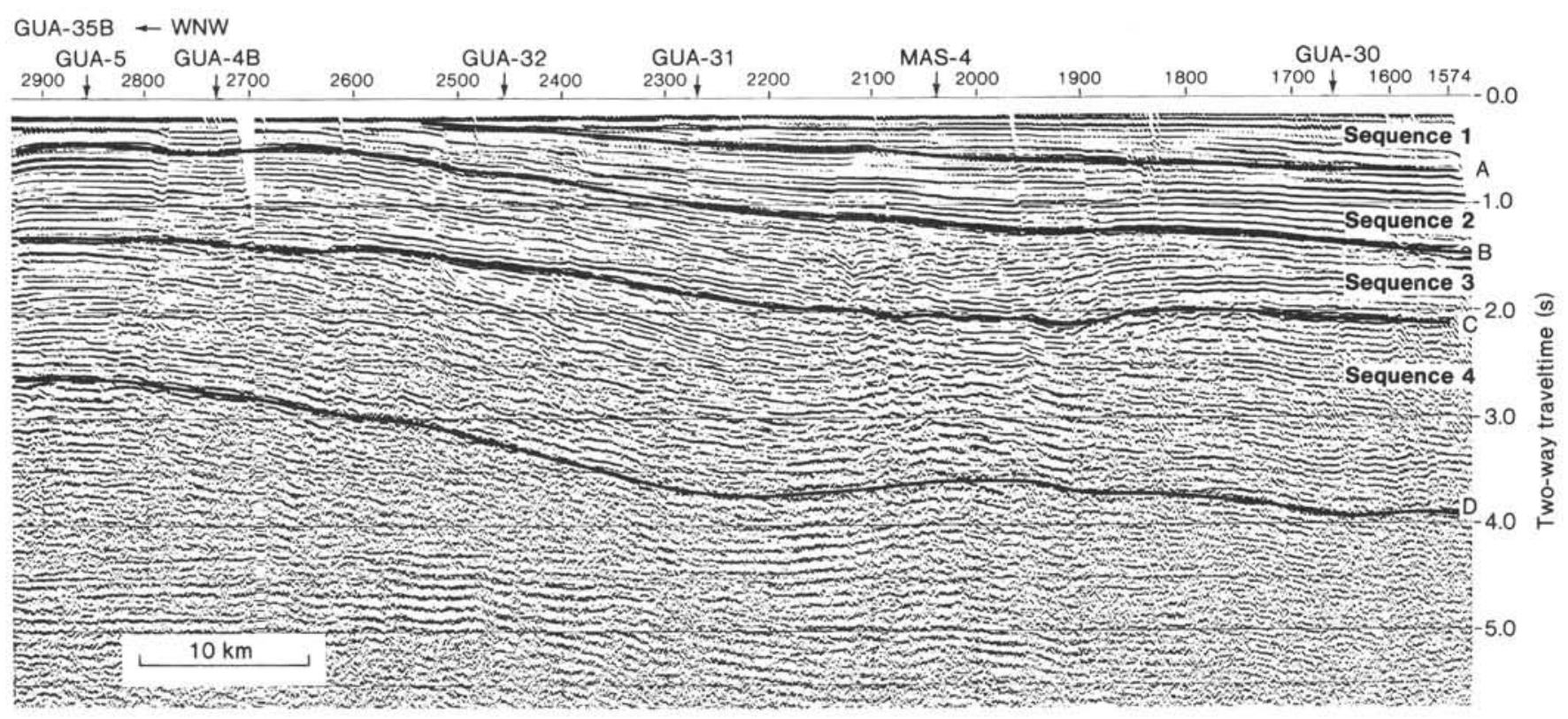

Figure 8. Seismic line GUA-35B. This line ties together many of the dip lines on the shelf and permits the tracing of horizons A to D. Sequences 2 and 1 thin and pinchout respectively to the northwest across a structural high (see Fig. 4 for identification of Sequences 2 through 4). Sequence 3 does not thin along this line.

(1979) to represent tectonic uplift, boundary C is not. According to Seely, the structural high at the shelf edge underwent only moderate subsidence (accommodating $500 \mathrm{~m}$ of upper bathyal Miocene sedimentation), with greater subsidence forming the landward basin. An early to middle Miocene subsidence of DSDP Site 496 from shelf to lower bathyal depths (von Huene et al., 1980) indicates that the continental slope seaward of the shelfedge high subsided contemporaneously with the shelf basin.

\section{Sequence 3}

According to well data, Sequence 3 is of the early to middle Miocene (Seely, 1979). An upper Oligocene and lower Miocene hemipelagic clay with granules and cobbles of chalk and limestone at Site 494 on the lower slope was interpreted by von Huene et al. (1980) as a distal terrigenous sequence. An age-equivalent sequence drilled at Site 496 on the mid-slope has been interpreted as a slightly more proximal terrigenous sequence. 


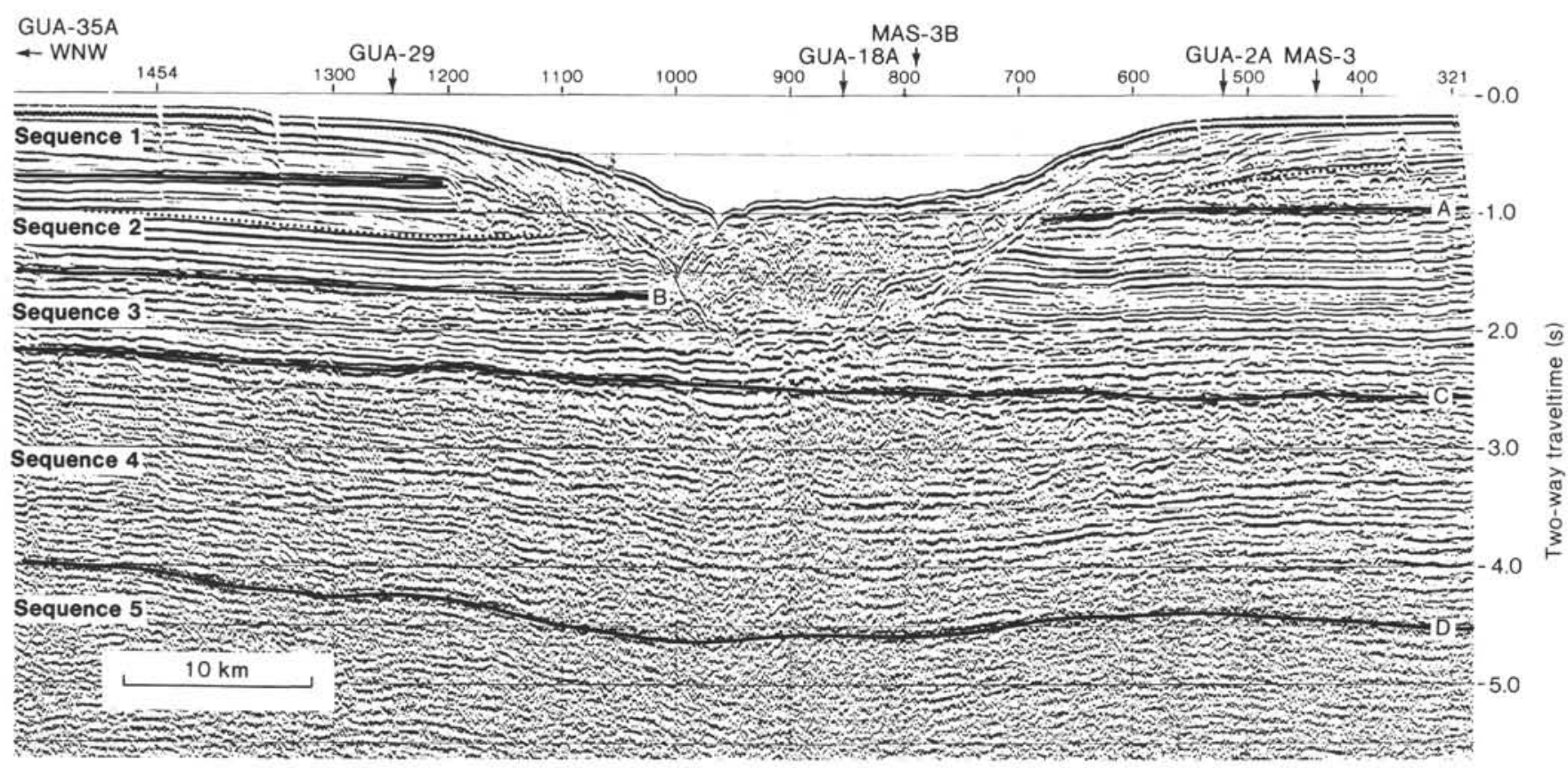

Figure 9. Seismic line GUA-35A across the head of San José Canyon. Note the contrast in the character of Sequence 1 and upper part of Sequence 2 that prograde toward the Canyon and the deeper sequences that do not.

C forms the lower boundary of Sequence 3, which is characterized by discontinuous subparallel reflections. GUA-35B reveals a large channel with thick, complex fill of Sequence 3 between shot points 1850 and 2200 (Fig. 8). The fill is disturbed by small-scale faulting, perhaps associated with compaction (SP 1900-2100, $1.5-2.0 \mathrm{~s})$. The continuation seaward of the filled channel is seen on GUA-33A between shot points 5400 and 5800 at 1.4 to $1.8 \mathrm{~s}$ (Fig. 6). To the southeast, San José
Canyon formed another conduit for sediment. On MAS3B (Fig. 10) the canyon axis cuts Sequence 3, though with degeneration of data below the Canyon it is impossible to discern to what depth. Apparent terraces and levees are closely associated with the Canyon, as is seen on GUA-35A and MAS-3B (Figs. 9 and 10).

Parallel to subparallel, fairly continuous reflections dominate Sequence 3 on the dip lines across the basin. This pattern is interrupted near the shelf edge on

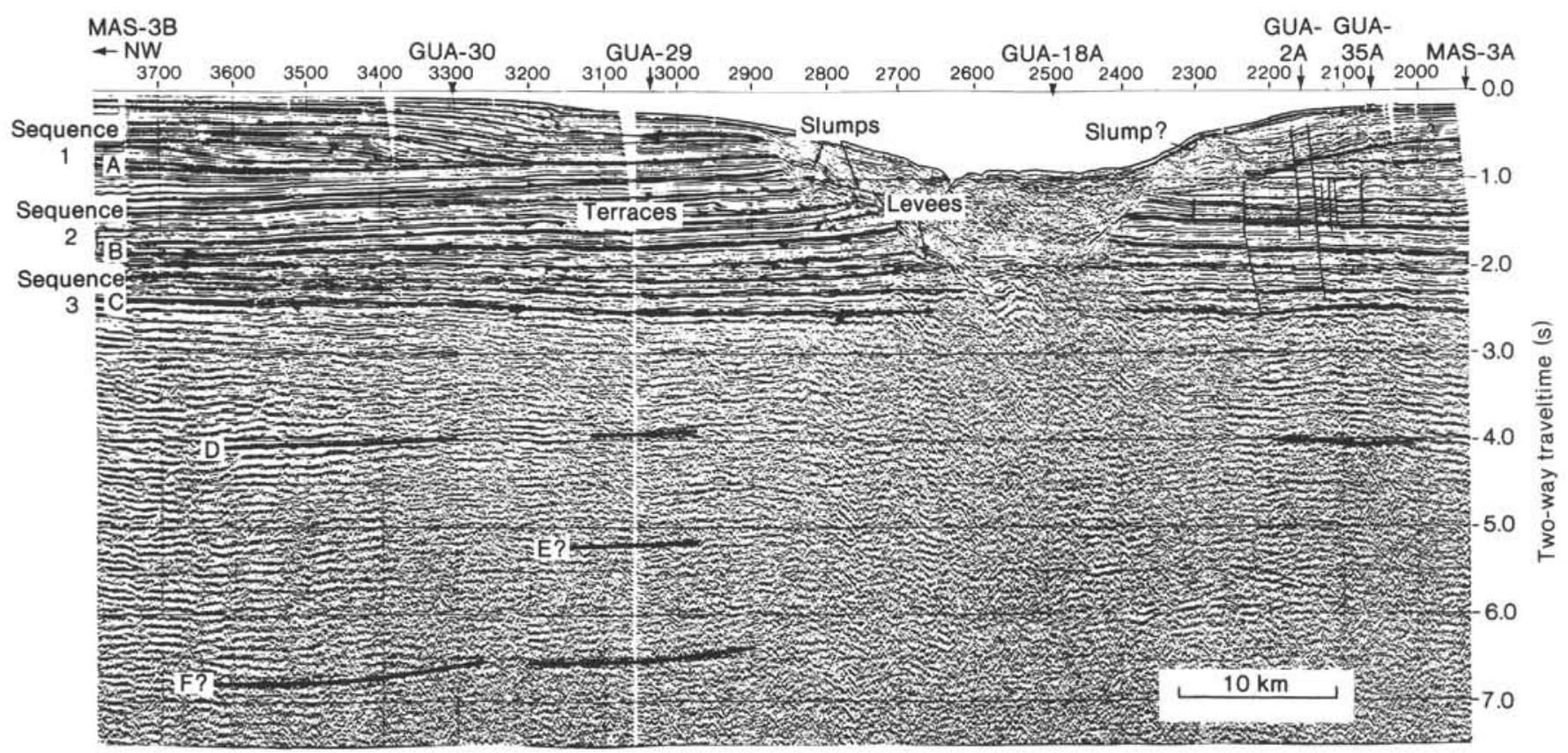

Figure 10. Seismic line MAS-3B. Note Sequence 1, which progrades toward San José Canyon, in contrast to the deeper sequences, which are truncated by the canyon fill. 
GUA-4B (Fig. 5, SP 2400-2600) and GUA-5 (Fig. 4, SP 300-600) where features having a mounded external form occur. These downlap landward across older sediments and are onlapped by overlying units. The mound on GUA-5 (Fig. 4) is dissected by channeling between shotpoints 475 and 550 . To the southeast, dip line GUA-30 traverses the shelf at a lower angle than the two lines just described and shows increasingly chaotic patterns toward the shelf edge (Fig. 14, SP 2100-2700). Between shot points 2300 and 2600 there is some indication of cut-and-fill. The sequence boundaries are essentially lost in this complex zone. Where GUA-30 crosses it, GUA33A exhibits complex, discordant, and chaotic patterns (Fig. 6). These patterns mark the seaward continuation of the buried channel from GUA-35 (Fig. 8). The complex shelf-edge patterns may be the result of episodes of deposition and subsequent reworking or of rapid sediment influx from several directions. Probably they are best interpreted as a product of superimposed, channeled progradational lobes.
On dip lines GUA-2A and GUA-29, which cross the shelf edge near San José Canyon (Figs. 11 and 12), Sequence 3 shows somewhat simpler, parallel to subparallel, fairly continuous reflections across the shelf. However, on most of the dip lines, and accentuated on GUA-4B and GUA-2A (Figs. 5 and 11), is illustrated the seaward thickening wedge of Sequence 3 . This general form is difficult to explain if the shelf-edge high was at its present position at the time of deposition. The seaward thickening is explicable only if the present shelf edge was at a lower level during the deposition of Sequence 3 and was later uplifted relative to the basin. The shelf margin must have been subsiding slowly during the early Miocene to accommodate the kilometer or so of upper bathyal to neritic Sequence 3. The early-middle Miocene subsidence of DSDP Site 496 may be inferred to have affected the adjacent shelf area, which thereby explains the seaward thickening of Sequence 3.

The one exception is line MAS-3A, which crosses the shelf edge far to the east of the other lines (Fig. 13). On

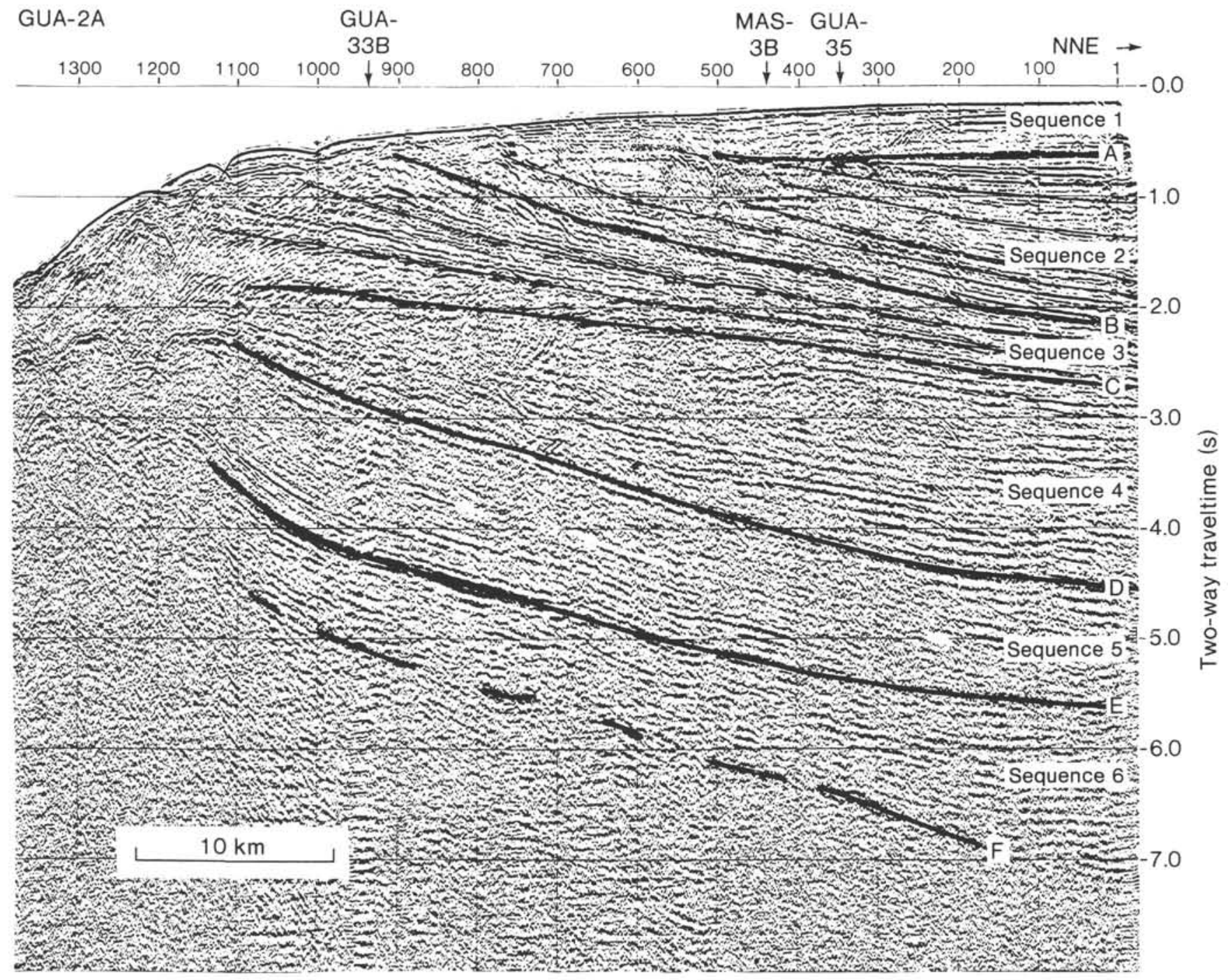

Figure 11. Seismic line GUA-2A across the shelf just to the east of San José Canyon. Note particularly the onlapping of Sequence 4 onto horizon D and the great seaward thickening of Sequence 3 before it is truncated at the shelf edge. 
SEISMIC STRATIGRAPHY, CONTINENTAL SHELF OFFSHORE GUATEMALA

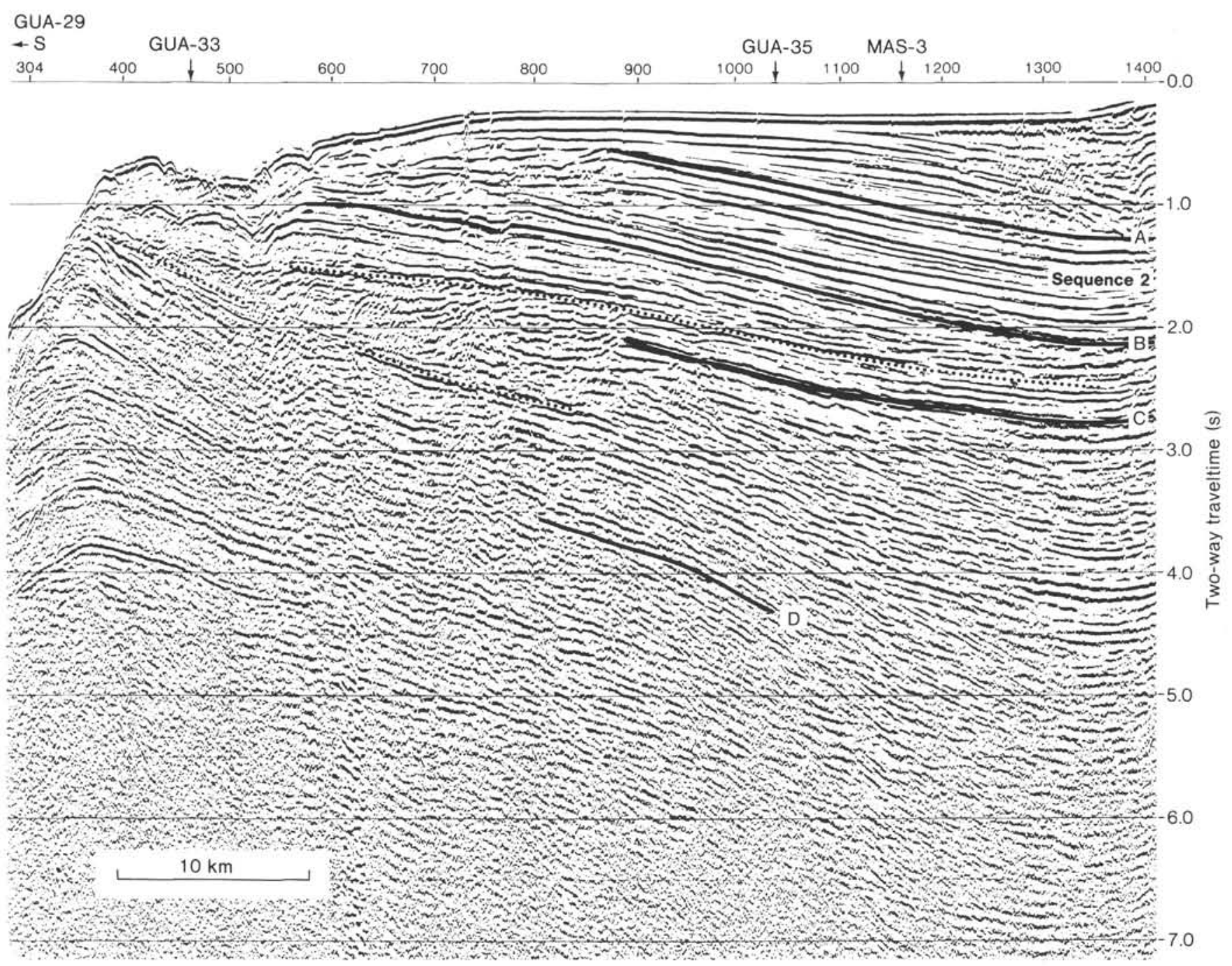

Figure 12. Seismic section GUA-29 showing the constant thickness of Sequence 2 beneath horizon A and the landward and seaward progradation of Sequence 1 on top of horizon A. Seaward of the termination of horizon A Sequence 2 is truncated by erosion.

this line Sequence 3 thins toward the shelf edge by progressively onlapping unconformity $\mathrm{C}$. This line suggests that the shelf edge was segmented in the Miocene with a different structural style west of $90^{\circ} 15^{\prime} \mathrm{W}$ from that to the east. Apparently to the east the shelf edge stood high and the sediments onlapped the structural high, whereas to the west there was a seaward-sloping surface on which the sediments accumulated in seaward-thickening packages.

\section{Sequence 2}

In contrast to the reflection configuration of Sequence 3 , Sequence 2 exhibits more continuous, parallel to subparallel reflections. Boundary B, which separates Sequences 2 and 3 , is a strong, continuous reflection characterized by subtle erosional truncation, as on MAS-3B (SP 3100-3400; Fig. 10) and GUA-35A (SP 1300-1454; Fig. 9). Sequence 2 extends to the northwest on GUA$35 \mathrm{~B}$ where B truncates the complex channel fill of Sequence 3 (SP 1900-2200; Fig. 8) by erosion. No buried channel is visible in Sequence 2. To the southeast across San José Canyon, the reflection configuration along strike is fairly similar to that to the northwest (Figures 9, 10, and 13). At the northwest end of the grid GUA-4B and -5 show apparent truncation of the seaward-thickening wedge of Sequence 3 (Figs. 4 and 5). Here Sequence 2 does not thicken seaward, nor does it on the dip lines to the southeast.

Evidence of progradation across the shelf is found on the seismic reflection lines, though such features are more limited in areal extent than in Sequence 3. Crossing several minor unconformities within Sequence 2 on GUA-29 are progradational clinoforms that retreat landward with time (Fig. 12; SP 650-1100). Sequence 2 reflects slow subsidence of the basin or the entire margin after a brief hiatus represented by $\mathrm{B}$.

\section{Sequence 1}

A different depositional environment is reflected by Sequence 1. On MAS-3B and GUA-35 thick sequence of progradational clinoforms overlies boundary A, a weak, discontinuous reflection that represents a major unconformity (Figs. 8, 9, and 10). On MAS-3B, Sequence 1 consists of a series of sigmoidal progradational units 


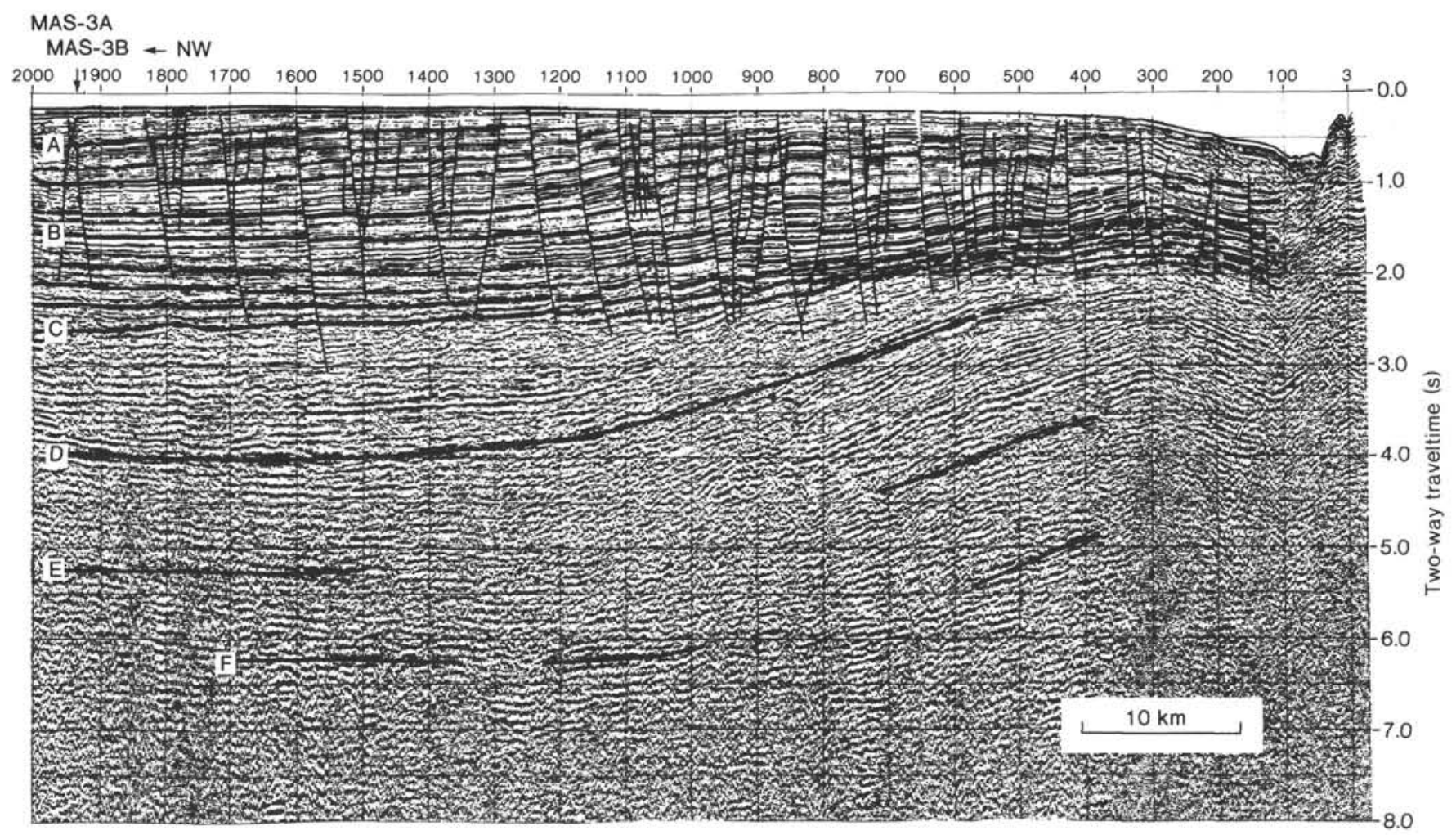

Figure 13. Seismic line MAS-3A. This line runs toward the shelf-edge high to the southeast. The section is broken by numerous normal faults, which are less evident in lines to the northwest. Sequence 3 between horizons $C$ and B thins toward the shelf edge on this line in contrast to the other lines. Subsidence of the shelf edge during the early Miocene must have been less in this region than to the northwest.

building southeastward toward and into the Canyon. Similar units are seen on GUA-35. By contrast, on GUA-29 and -30 , broad, gently arching mounds are seen downlapping on A (Figs. 12 and 14). Overlying sediments onlap these mounds on the northern sides, and on GUA-29 (SP 1300-1400) these onlapping sediments appear chaotic. The mounds on GUA-29 and -30 are probably views of the same prograding lobe or fan. The chaotic nature of portions of the units overlying the fan may reflect slumping of sediment down the side of the fan. Line GUA-2A (Fig. 11), which is perpendicular to line GUA-35, shows Sequence 1 to be of nearly uniform thickness and prograding gently seaward. In the perpendicular direction, however, Sequence 1 progrades rapidly toward the Canyon, indicating the strong influence of San José Canyon on the local development of Sequence 1. Toward the northwest, Sequence 1 pinches out against an apparent structural high along line GUA-35.

Site 494 on the lower slope yielded a Pliocene-Pleistocene unit of mud and mudstone with a secondary component of volcanic glass and a Holocene-Pleistocene unit with plant debris and pelecypod and ostracode remains providing evidence of reworking of shallow-water material (von Huene et al., 1980). These sediments transported from the shelf and upper slope demonstrate that there was a relatively high rate of sediment supply from the shelf during the Quaternary. Because much sediment must have been trapped on the shelf in the forearc basin, a great amount of sediment must have been available to supply the lower slope as well. A shelf deltaic complex would provide such a supply, indicating a Quaternary age for Sequence 1.

\section{CONCLUSIONS}

The seismic reflection data described here together with the seismic data and drilling results of Seely (1979) suggest that Cretaceous and Paleocene sedimentation in the region was on a southward-dipping slope and that the forearc basin was initiated in an episode of structural uplift concentrated at the present shelf edge with associated landward tilting of sequences and was perpetuated by subsidence behind the structural high. Evidence indicates that oceanic crust may floor the basin, though the tracing of this basement through the seismic grid is difficult. Failure and uplift of a sliver of oceanic crust during the latest Paleocene or earliest Eocene, as is postulated by Seely (1979), may reflect a contemporaneous reorientation of the southern Middle America Trench (Malfait and Dinkelman, 1972).

Cretaceous Sequence 6 downlapped and prograded across the top of an older surface that dipped southward. Because horizon E does not significantly truncate Sequence 6 , the northward thickening of 6 is probably an original sedimentary feature related to seaward transport from a source to the north (present coordinate frame of reference). Because Sequence 5 like Sequence 6 is an abyssal sediment sequence, the northward onlap of Sequence 5 onto horizon $\mathrm{E}$ suggests deep-sea-basin sedimentation such as abyssal-plain sedimentation onlapping the continental slope or rise. Again E, at the time 


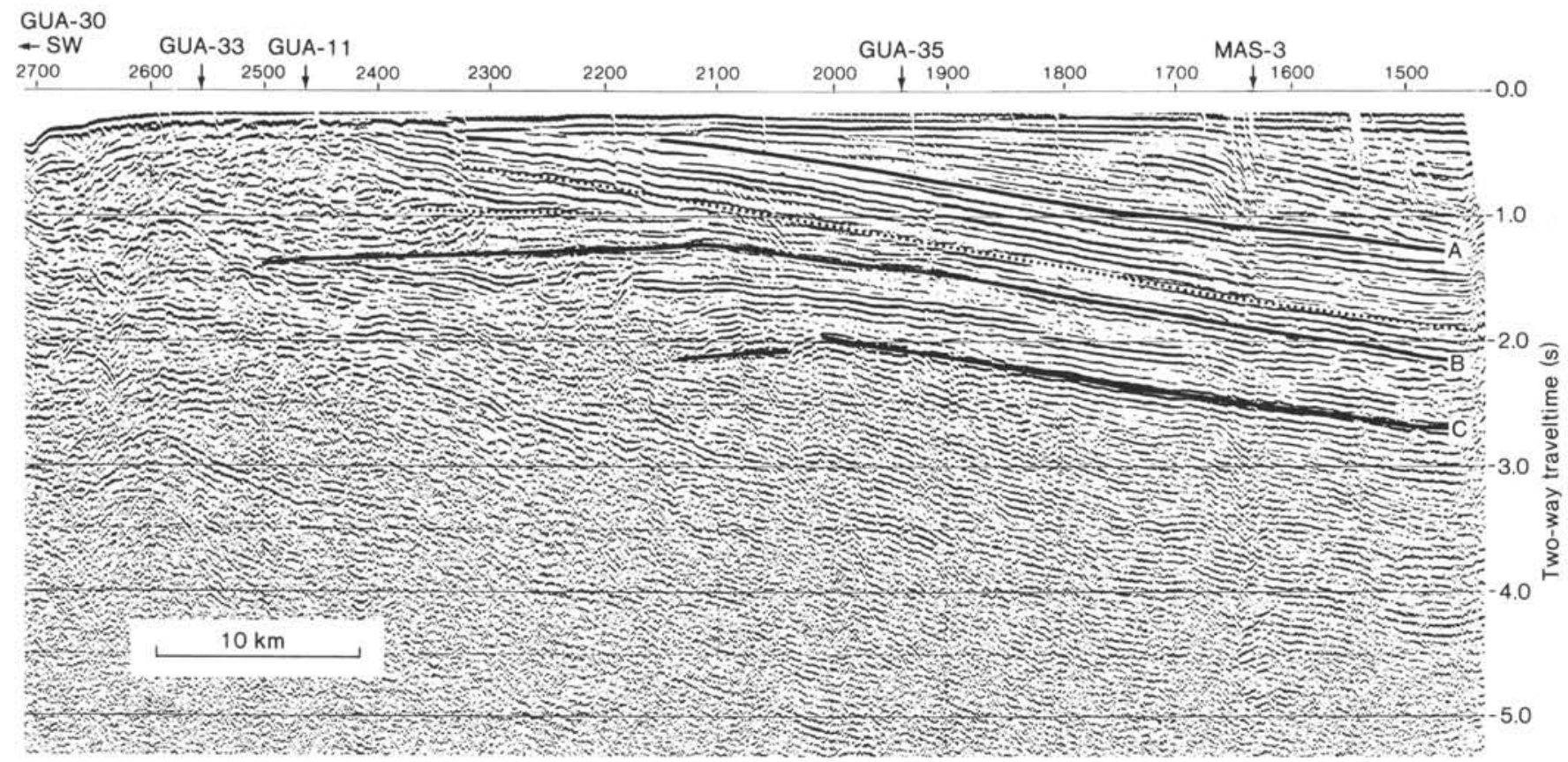

Figure 14. Seismic section GUA-30 showing the constant thickness of Sequence 2 beneath horizon A and the thickening of Sequence 2 toward the shelf edge seaward of the termination of horizon A where a chaotic mound reflects a depositional lobe of a fan.

of deposition of Sequence 5, would have been a southward and seaward-dipping surface.

With the early Eocene uplift documented by Seely there may have been a reversal of dips, and Eocene and Oligocene Sequence 4 onlapped the landward and northward-dipping surface D. Horizon $\mathrm{C}$, which truncates the top of Sequence 4, is onlapped seaward by Sequence 3. Sequence 3, which has a maximum thickness just landward of the shelf edge, was deposited in upper bathyal depths, indicating 1 to $2 \mathrm{~km}$ of subsidence of the shelf edge to accommodate the thickness of Sequence 3 during the early and middle Miocene. If the landward section of Sequence 3 was also deposited in upper bathyal depths, then early and middle Miocene subsidence was greater near the shelf edge where Sequence 3 is thickest than farther landward.

A change in the location of the center of maximum subsidence occurred in the mid-Miocene. Sequences 1 and 2 thicken landward toward the center of the forearc basin. Some process must have arrested the subsidence of the shelf edge and slope. At this point we can only speculate on the various processes that might lead to changes in the location of maximum subsidence. Isostatic loading of the region by the growing volcanic arc would cause greater subsidence closer to the arc. During the early and middle Miocene, the shelf edge and continental slope underwent greater subsidence than the shelf farther arcward. Tectonic erosion along the Benioff zone may have removed material from beneath the shelf edge and slope in the early Miocene and then stopped by the late Miocene, at which time isostatic loading by the volcanic arc became the dominant factor.

The sediment sequences represent periods of deposition, whereas the unconformities and associated canyon development represent periods of erosion. The reflec- tion geometries internal to Sequences 3 and 1 and to a lesser extent Sequence 2 suggest that parts of these units were deposited as lobes of deltaic fans near the shelf edge. More distal facies were encountered on the slope by DSDP drilling. To the west of San José Canyon Sequence 3 thickens seaward as it does just to the east on line GUA-2. However, still farther east Sequence 3 thins seaward, suggesting that during Sequence 3 time there was a difference in the extent of subsidence of these two parts of the shelf edge. Perhaps this difference is related to a segment boundary suggested by Carr et al. (1974, 1977) and Carr (1976).

The major unconformities of the forearc basin were apparently coeval with major plate reorganizations. A major reorganization of the Pacific-Farallon spreading center, which occurred in the late Paleocene (Atwater and Menard, 1970), may have coincided with or preceded the uplift of the structural high at the Guatemala shelf edge (Seely, 1979) and the formation of unconformity D. Hey (1977) has noted that approximately 25 m.y. ago in the late Oligocene or early Miocene, the Farallon Plate split apart, forming the Cocos and Nazca plates. This was part of a more general northeast Pacific Plate reorganization that was initiated when the Pacific-Farallon spreading center intersected the subduction zone bordering North America south of the Mendocino Fracture Zone (Atwater, 1970; Atwater and Menard, 1970; Menard, 1978) and that culminated in the formation of the Guadalupe Plate, bounded by the Murray Fracture Zone to the north and by the Cocos-Nazca spreading ridge to the south (Mammerickx and Klitgord, 1982). This reorganization may have coincided in time with unconformity C. From 12.5 to $11 \mathrm{~m} . \mathrm{y}$. ago in the middle Miocene another plate reorganization occurred that led to a much shortened Pacific-Cocos plate boundary; this 
coincided in time with unconformity B. The mid-Miocene marked a significant phase of Central American volcanism with the eruption of voluminous ignimbrites in northern Central America and southern Oaxaca, Mexico. Thousands of cubic kilometers of ignimbrites accumulated, including more than $5000 \mathrm{~km}^{3}$ in Honduras alone. This phase of volcanism ended and was followed by deformation in the late Miocene (Williams and McBirney, 1969; Weyl, 1980).

The Miocene reorientations of plate boundaries and the increase in the volcanic activity onshore accompanied renewed tilting and subsidence of the margin. The forearc basin subsided under the great volume of volcanogenic sediment trapped there, and this, with the tremendous mass of the arc during the Miocene-Pliocene peak, possibly caused regional subsidence diminishing away from the volcanic arc. Thus the landward thickening of Sequences 1 and 2 may have been caused in part at least by isostatic loading of the arc, not tectonic uplift of the shelf edge and slope.

Between about 6.5 and 3.5 m.y. ago in the Pliocene the Pacific-Cocos spreading center jumped from the Mathematician spreading ridge to the present East $\mathrm{Pa}$ cific Rise. This eastward jump would be the same age approximately as unconformity $\mathrm{A}$ and would have led to closer proximity of the hot spreading ridge of the Guatemala shelf edge. Possibly increased lithospheric temperatures beneath the shelf edge produced the uplift that caused unconformity A.

The causal relationship between events on either side of the Trench is more difficult to establish than the temporal relationship. Menard (1978) has pointed out that the motions of small plates breaking off the much larger Farallon Plate will be quite different from the Farallon Plate motion. The direction and rate of lithosphere plunging into the aesthenosphere at a trench is determined by the sum of forces acting along the entire length of the rigid plate at the subduction zone. As a plate breaks into smaller plates the forces acting on each small plate become independent of the other plates, and the new small plates take on new individual motions with respect to neighboring plates. Consequently the convergence rate across the Middle America Trench may change with each new plate reorganization. Changing convergence rates may directly affect the lithosphere in the vicinity of the Trench. Also discrete plate reorganizations may lead to a jump of a ridge crest to a position closer to a subduction zone with accompanying elevation of lithospheric temperatures at the subduction zone. The same thing may happen more gradually with the evolution of plate boundaries not accompanied by discrete reorganizations. Elevated temperatures may lead to uplift of a plate margin at the subduction zone.

Other factors affecting events in the forearc offshore Guatemala are the tectonic developments on the far side of the Caribbean Plate. In the Paleocene the Greater Antilles on the Caribbean Plate began interacting with Yucatan and by the early Eocene they were colliding with the Bahamas (Burke et al., 1984). This collision event undoubtedly stalled the northeastward motion of the Caribbean Plate and contributed to the development of subduction off western Central America.

\section{ACKNOWLEDGMENTS}

Most of the work for this chapter including the data acquisition and processing was done while the authors were in Galveston at the University of Texas Marine Science Institute. This work was supported by JOI, Inc. as part of the site survey for Guatemala drilling. The chapter has benefited from numerous reviews by Richard Buffler, Wulf Gose, Roland von Huene, Kenneth McMillen, and Don Hussong.

\section{REFERENCES}

Atwater, T., 1970. Implications of plate tectonics for the Cenozoic tectonic evolution of Western North America. Geol. Soc. Am. Bull., 81:3513-3536.

Atwater, T., and Menard, H. W., 1970. Magnetic lineations in the northeast Pacific. Earth and Planetary Sci. Lett., 7:445-450.

Aubouin, J., von Huene, R. E., et al., 1982a. Init. Repts. DSDP, 67: Washington (U.S. Govt. Printing Office).

Aubouin, J., von Huene, R. E., et al., 1982b. Leg 84 of the deep sea drilling project: subduction without accretion: Middle America Trench off Guatemala. Nature, 297:458-460.

Burke, K., Cooper, C., Dewey, J. F., Mann, P., and Pindell, J. L., 1984. Caribbean tectonics and relative plate motions. In Hargrave, R. and Bonini, W. (Eds.), The Caribbean-South American Plate Boundary and Regional Tectonics. GSA Memoir 162:31-64.

Carr, M. J., 1976. Underthrusting and Quaternary faulting in northern Central America. Geol. Soc. Am. Bull., 87:825-829.

Carr, M. J., and Stoiber, R. E., 1977. Geologic setting of some destructive earthquakes in Central America. Geol. Soc. Am. Bull., $88: 151-156$.

Carr, M. J., Stoiber, R. E., and Drake, C. L., 1974. The segmented nature of some continental margins. In Burke, C. A., and Drake, C. L. (Eds.), The Geology of Continental Margins: New York (Springer-Verlag), pp. 105-114.

Couch, R., and Woodcock, S., 1981. Gravity and structure of the continental margins of southwestern Mexico and northwestern Guatemala. J. Geophys. Res., 86:1829-1840.

Dengo, G., 1962. Tectonic-igneous sequence in Costa Rica. In Engel, A. E. J., James, H. L., and Leonard, B. F. (Eds.), Petrologic Studies: a volume to Honor A. F. Buddington, Geol. Soc. Am. Bull., pp. 133-161.

Dickinson, W. R., and Seely, D. R., 1979. Structure and stratigraphy of forearc regions. Am. Assoc. Petrol. Geol. Bull., 63(1):2-31.

Hey, R., 1977. Tectonic evolution of the Cocos-Nazca spreading center. Geol. Soc. Am. Bull., 88:1404-1420.

Ibrahim, A. K., Latham, G. V., and Ladd, J. W., 1979. Seismic refraction and reflection measurements in the Middle America Trench offshore Guatemala. J. Geophys. Res., 84(B10):5643-5649.

Ladd, J. W., Ibrahim, A. K., McMillen, V. J., Latham, G. V., and von Huene, R. E., 1982. Interpretation of seismic reflection data of the Middle America Trench offshore Guatemala. In Aubouin, J., von Huene, R., et al., Init. Repts. DSDP, 67: Washington (U.S. Govt. Printing Office), 675-689.

Ladd, J. W., Ibrahim, A. K., McMillen, K. J., Latham, G. V., von Huene, R., et al., 1978. Tectonics of the Middle America Trench offshore Guatemala. In International Symposium on the Feb. 4, 1976, Guatemala Earthquake and the Reconstruction Process, Agency for Int. Develop., Guatemala City, Guatemala, May 1978.

Lundberg, N., 1982. Evolution of the slope landward of the Middle America Trench, Nicoya Peninsula, Costa Rica. In Leggett, J. (Ed.), Trench-Forearc Geology: Sedimentation and Tectonics in Modern and Ancient Active Plate Margins, Geol. Soc. London, 131-150.

Malfait, B. T., and Dinkelman, M. G., 1972. Circum-Caribbean tectonic and igneous activity and the evolution of the Caribbean Plate. Geol. Soc. Am. Bull., 83(2):251-271.

Mammerickx, J., and Klitgord, K. D., 1982. Northern East Pacific Rise: evolution from 25 mybp to the Present, Part II. J. Geophys. Res., 87:6751-6760.

Menard, H. W., 1978. Fragmentation of the Farallon Plate by pivoting subduction. J. Geol., 86:99-110.

Moore, C., Watkins, J. S., Buchman, S. B., Beghtel, F. W., Butt, A., et al., 1979. The Middle America Trench off Mexico. Geotimes, 24(9):20-22.

Seely, D., 1979. The evolution of structural highs bordering major forearc basins. In Watkins, J. S., Montadert, L., and Dickerson. P. W. (Eds.), Geologic and Geophysical Investigations of Continental Margins, Am. Assoc. Pet. Geol. Mem., 29:245-260. 
Seely, D. R., Vail, P. R., and Walton, G. G., 1974. Trench-slope model. In Burk, C. A., and Drake, C. L. (Eds.), The Geology of Continental Margins: New York (Springer-Verlag), pp. 249-260.

Shipley, T. H., Ladd, J. W., Buffler, R. T., and Watkins, J. S., 1982. Tectonic processes along the Middle America trench inner slope. In Leggett, J. (Ed.), Trench and Forearc Geology: Sedimentation and Tectonics in Modern and Ancient Active Plate Margins, Geol. Soc. London pp. 95-106.

Shor, G. G., Jr., and Fisher, R. L., 1961. Middle America Trench: seismic refraction studies. Geol. Soc. Am. Bull., 72:721-730.

Vail, P. R., Mitchum, R. M., Todd, R. G., et al., 1977. Seismic stratigraphy and global changes of sea level. In Payton, C. E. (Ed.), Seismic Stratigraphy - Applications to Hydrocarbon Exploration: Am. Assoc. Petrol. Geol. Mem., 26:49-212. von Huene, R., and Aubouin, J., et al., 1980. Leg 67: the Deep Sea Drilling Project Mid-America Trench transect off Guatemala. Geol. Soc. Am. Bull., 91(1):421-432.

Weyl, R., 1980. Geology of Central America (2nd ed.): Berlin (Gebruder Borntraeger).

Whitcroft, H. T., 1944. The bathymetry of the Central American region, west of Mexico and northern Central America. Am. Geophys. Trans., Part IV, pp. 605-606.

Williams, H., McBirney, A. R., 1969. Volcanic history of Honduras. California University Publ. Geol. Sci., 85:1-101.

Date of Initial Receipt: 5 December 1983

Date of Acceptance: 30 March 1984 